„Tehetség, szorgalom, hivatás”

\author{
Tanulmánykötet
}

Kézirat lezárva: 2021. június 25. 
Kiadja:

a Magyar Rendészettudományi Társaság

Vám- és Pénzügyőri Tagozata

Szerkesztette:

Csaba Zágon és

Zsámbokiné Ficskovszky Ágnes

Felelős kiadó:

Szabó Andrea

ISBN: 978-615-81879-0-9

A mú szerzői jogilag védett. Minden jog, így különösen a sokszorosítás, terjesztés és fordítás joga fenntartva. A mű a kiadó írásbeli hozzájárulása nélkül részeiben sem reprodukálható, elektronikus rendszerek felhasználásával nem dolgozható fel, azokban nem tárolható, azokkal nem sokszorosítható és nem terjeszthetô. 
Szerzők

Lektorok

Lectori Salutem!

Tanulmányok

Christián László - Lippai Zsolt: Kakukktojás vagy új rendészeti alappillér?

Gonda Éva: Az Europol hospitáció hasznosítása a pénzügyi nyomozók képzése terén

Kakócz Krisztián - Vedó Attila: A toloncolás szabály- és szervezetrendszere a második világháború előtt

Kovács Gábor: A vezetői kompetenciák fejlesztésének lehetőségei a Rendészettudományi Kar hallgatóinak körében

Magasvári Adrienn: Egy új jogviszony „születése” - az adó- és vámhatósági szolgálati jogviszony vizsgálata ..

Molnár Katalin: Mi harminc? Tudománymetria helyett - Szerzőtársas játék................................ 87

Nyeste Péter: A modern bűnügyi hírszerzés modelljeinek fejlődése ............................................ 103

Pajor Andrea: Adóigazgatási tisztviselők képzése .

Sallai János - Borszéki Judit: Egy megvalósítható utópia? Közös munkanyelv keresése a nemzetközi rendőri együttmúködés kezdetén.

Suba László: Nyelvhelyesség a közszférában: Létkérdés vagy úri huncutság?

Szabó Andrea - Hájer Tamara: A vámfelsőoktatás uniós elismerési eljárásának elemei

Szlifka Gábor: Okos adózás, okos adóigazgatás - Minden ami okos, de mit is jelent pontosan?

Kutatási eredmények

Balla József - Kiss Lajos: A rendvédelmi szervező szakirányú továbbképzési szak indításának legfontosabb tapasztalatai.

Borzán Anita - Szekeres Bernadett: A digitalizáció hatása a gazdasági szakismeretek és a számvitel oktatására.

Duchon Jenő: Tanulási stílus és játékos típus összevetése felnőtteknél, az oktatási folyamat játékosítása céljából

Erdős Ákos - Somogyi Ágnes: Koffeinhasználat és koffeinhasználati zavar vizsgálata rendészeti hallgatók körében

Halasi Nóra: Feltáró kutatás a hivatástudat és motiváció jelentőségének vizsgálatára, a Hajdú-

Bihar Megyei Adó- és Vámigazgatóság személyi állományának összefüggésében 251 


\title{
Gonda Éva*: Az Europol hospitáció hasznosítása a pénzügyi nyomozók képzése terén
}

\begin{abstract}
Absztrakt
A Bűnüldözési Együttműködés Európai Uniós Ügynöksége (Europol) az Európai Unió bűnüldöző hatósága, amely segíti a tagállami hatósági szervek bűnmegelőzési, bűnfelderítési és bűnüldözési munkáját. Magyarország 2006-ban indította gyakornoki programját az Europolnál és küld bűnügyi szakterületen dolgozó nyomozati és felderítő szakértőket a szervezethez. A gyakornokok három hónapos rotációs rendszerben ismerhetik meg az Europol felépítését, feladatát, munkáját, továbbá ismereteket szereznek az Europol tagállami nyomozásokat támogató szerepéről. A gyakornokok által megszerzett tudást szükséges ismertetni az aktív nyomozói állománnyal, hogy a rendelkezésre álló együttműködési lehetôségeket minél szélesebb körben lehessen felhasználni. A cikk általános jelleggel mutatja be az Europol tevékenységét, illetve a hospitációs rendszert. A szerzó javaslatot tesz arra, hogy a pénzügyi nyomozók továbbképzését egészítsék ki a gyakornoki programban részt vett kollégák tapasztalataival, hogy azok megfelelő módon rögzítésre, továbbadásra, felhasználásra kerülhessenek, mert a jelenlegi nyomozói állomány többségének még nincs pontos ismerete az Europol által biztosított támogató tevékenységrôl.
\end{abstract}

Kulcsszavak: nemzetkëzৃi bünügyi együttmükëdés, Europol, gyakornoki program

\begin{abstract}
The European Union Agency for Law Enforcement Cooperation (Europol) is the European Union's law enforcement agency assisting the Member States' authorities in crime prevention, crime detection and law enforcement work. Hungary launched its internship program at Europol in 2006 and sent criminal investigation and intelligence experts to the organisation. The interns can learn about the structure, work and mission of Europol throughout the three-month rotation system and have the opportunity to gain knowledge of the organisation's supporting role in Member States' investigations. It is necessary to share the experiences acquired by the interns with the active investigative staff of their home agency to exploit international cooperation opportunities in criminal matters as widely as possible. The article provides a general overview of Europol and on the internship system. The author proposes that the training of financial investigators could be supplemented by the experience of colleagues involved in the internship program. This knowledge can be properly recorded, transferred, and used, as most current investigators do not yet have awareness of Europol's support opportunities.
\end{abstract}

Keywords: international law enforcement cooperation, Europol, internship programme

* Gonda Éva, dr., pénzügyőr főhadnagy, nyomozó, Nemzeti Adó- és Vámhivatal Középmagyarországi Bűnügyi Igazgatósága, https://orcid.org/0000-0002-5249-9224, gonda.eva@,nav.gov.hu 


\section{Bevezető gondolatok, célok}

A Nemzeti Adó- és Vámhivatal (NAV) hivatásos állományába tartozó pénzügyőr nyomozóként fontosnak tartom, hogy a nyomozati munkát minél hatékonyabbá tudjuk tenni.

A NAV nyomozati hatáskörébe utalt költségvetési csalások jelentős részének elkövetésére úgy kerül sor, hogy a felállított számlázási láncolatokba külföldi illetőségű gazdasági társaságok is bekerülnek, ezáltal a bűncselekményeknek külföldi szála keletkezik. Erre figyelemmel - a hatékony bűnüldözés érdekében - fontos feladat az érintett országok partner hatóságaival történő gyors és hatékony együttműködés.

A nemzetközi bűnügyi együttműködésben, illetve annak megkönnyítésében nagy szerepet játszik az Europol. E szervezethez a NAV Bủnügyi Főigazgatósága is delegálhat gyakornokokat annak érdekében, hogy munka közben ismerkedjenek az együttmúködés lehetőségeivel. A delegált személyek három hónap időtartamot tölthetnek el az Europolnál, amely során megismerik a szervezet felépítését, működését, munkáját, továbbá megismerkednek olyan rendszerekkel és együttmúködési formákkal, amelyek a magyar bűnüldöző hatóságok munkáját is nagyban megkönnyíthetik, segíthetik.

Az így megszerzett tudást pedig - a lehetőségeinkhez mérten - az aktív nyomozói állománnyal ismertetni kell annak érdekében, hogy növeljük a tudatosságot a nemzetközi együttmúködés lehetôségei terén és egy-egy büntetőeljárás során hasznosíthassuk a tapasztaltakat. A tanulmány célja, hogy bemutassam a gyakornoki program során megszerezhető ismeretköröket, illetve az, hogy az aktív pénzügyi nyomozói állomány képzése terén ezek felhasználására tegyek javaslatot.

A téma jellegéből adódóan nem csak a kapcsolódó szakirodalmak felhasználására koncentráltam, hanem törekedtem arra is, hogy hospitációs programban részt vett kollégákat is megkérdezzek saját tapasztalataikról. Az interjúk egyoldalúságát pedig úgy oldottam fel, hogy nem csak a NAV-os, hanem a rendőrség hospitációs programjában részt vett kollégával is készítettem interjút.

\section{Nemzetközi bűnügyi együttmüködés az Europolon keresztül}

\section{Az Europol tevékenysége}

Az Europol 1999. július 1-én Európai Rendőrségi Hivatal néven kezdte meg működését, amelyhez minden tagállam felállított egy az Europolhoz telepített nemzeti összekötő irodát, illetve a tagállamban egy nemzeti egységet, hogy közvetíthessenek az Europol és a nemzeti hatóságok között. ${ }^{1}$ Előbbi a hágai Europol Magyar Összekötő Iroda (EMŐI), utóbbi pedig a Nemzetközi Bűnügyi Együttműködési Központ (NEBEK) szervezetén belül múködő Europol Nemzeti Iroda (ENI), amely Budapesten található. ${ }^{2}$

\footnotetext{
${ }^{1}$ HoRvÁTH Zoltán: Kézikönyv az Európai Unióról. HVG-Orac Lap- és Könyvkiadó Kft., Bp., 2007. p. 519.

2 Nemzeti Adatvédelmi és Információszabadság Hatóság: Tájékoztató EUROPOL rendszerről. https://www.naih.hu/tajekoztato-az-europol-rendszerr-l.html (Letöltve: 2021. március 13.)
} 
A szervezet indulására az Europol-egyezmény ${ }^{3}$ ratifikálását követően kerülhetett sor. A következő mérföldkő a 2010. január 1-én hatályba lépett tanácsi határozat ${ }^{4}$, amely jogforrás alapján az Europol kiterjesztett feladatköröket, illetve új jogi kereteket kapott. A gyakorlatban ez azt is jelentette, hogy a szervezet is teljes jogú uniós ügynökséggé vált.

A jelenleg hatályos szabályozás szerint az Europol elnevezése a Bűnüldözési Együttmúködés Európai Uniós Ügynöksége. ${ }^{5}$ A bűnüldöző hatóság fő feladata, hogy hozzájáruljon egy biztonságosabb Európa megteremtéséhez elsősorban a bűnügyi információk cseréjének előmozdítása, illetve azok elemzése segítségével. A szervezet célja, hogy az európai bűnüldöző hatóságok együttműködését és eredményességét javítsa a nemzetközi bűnözés súlyos formái, a szervezett bűnözés és a terrorizmus megelőzése, illetve leküzdése vonatkozásában. $^{6}$

Az Europol munkájával az Európai Unió összes tagállamát segíti, továbbá együttmúködik több Európai Unión kívüli ország partnerhatóságával, illetve nemzetközi szervezetekkel.

Munkájuk során az Európai Unió belső biztonságát veszélyeztető fenyegetésekkel - például: terrorizmus, nemzetközi kábítószer-kereskedelem, pénzmosás, szervezett jellegű csalások, embercsempészet, euró hamisítás, kiberbűnözés stb. - kapcsolatban nyújtanak segítséget a tagállamok számára. ${ }^{7}$

Meg kell jegyezni, hogy a nemzetközi bűnügyi együttmúködés napjaink egy igen dinamikusan változó területe, hiszen a szolgáltatások más országból való elérésének, az állampolgárok más országokba való mozgásának megkönnyítésével kapcsolatos vívmányokat a bűnelkövetők is figyelemmel kísérik, és ki is használják. Megfigyelhető a bűnözés szervezettségének növekedése, a bűnözés határon átnyúló jellege, amely olykor kiemelten nehéz feladat elé állítja a rendvédelmi szervek munkatársait. ${ }^{8}$

Egy-egy EU tagállam egymaga a legtöbb esetben nem tud hatékonyan fellépni az országokon átívelő, nemzetközi bűnözéssel szemben. Az Europol ehhez nyújt támogatást, célirányosan segíti a bűnügyi információszerzést, azok cseréjét, megosztását és az ügynökséghez küldött információk elemzését végzi tevékenysége során. ${ }^{9}$

Az Europol eseti alapon részt vesz még a tagállamok területén tevékenykedô, ún. Közös Nyomozó Csoportok munkájában, ahol speciális eszközökkel és információkkal segíti a bűntények felderítését. ${ }^{10}$

Az Europol az alábbi területeken nyújt támogatást a tagállamok részére:

\footnotetext{
3 Egyezmény az Európai Unióról szóló szerződés K.3. cikke alapján az Európai Rendőrségi Hivatal létrehozásáról

${ }^{4}$ Az Európai Rendőrségi Hivatal (Europol) létrehozásáról szóló 2009. április 6.-i, 2009/371/IB számú tanácsi határozat

5 Az Európai Parlament és a Tanács (EU) 2016/794 rendelete (2016. május 11.) a Bűnüldözési Együttmúködés Európai Uniós Ügynökségéről (Europol), valamint a 2009/371/IB, a 2009/934/IB, a 2009/935/IB, a 2009/936/IB és a 2009/968/IB tanácsi határozat felváltásáról és hatályon kívül helyezéséről. [Europol rendelet] 1. cikk 1. pont.

${ }^{6}$ A szervezet céljait és hatáskörét részletesen lásd uo. 3-4. cikkek.

${ }^{7}$ Az Europolról. https://www.europol.europa.eu/hu/about-europol (Letöltve: 2021. február 10.)

${ }^{8}$ SZONGOTH Richárd - VETTER Dániel: Nemzetközi bűnügyi együttműködés a kiberbűnözés területén. Belügyi Szemle 2018/7-8. szám pp. 7-21: 7. https://doi.org/10.38146/BSZ.2018.7-8.1

${ }_{9}^{9}$ Az Europolról. i. m.

${ }^{10}$ A Tanács 2002/465/IB kerethatározata (2002. június 13.) a közös nyomozócsoportokról (9) preambulumbekezdés
} 
- bűnügyi hírszerzés, információcsere megkönnyítése az egyes európai bűnüldöző hatóságok között a biztonságos információcsere-hálózati alkalmazás (SIENA ${ }^{11}$ ), illetve az Europol kulcsfontosságú információs $\left(\right.$ EIS $\left.^{12}\right)$ és elemző rendszerei $\left(\right.$ EAS $\left.^{13}\right)$ segítségével, ${ }^{14}$

- műveleti elemzés és támogatás nyújtása az egyes tagállami múveletek vonatkozásában,

- beszerzett információk alapján stratégiai jelentések és bűnügyi elemzések készítése,

- technikai támogatás, szakértelem biztosítása az Európai Unión belül lefolytatott nyomozásokhoz és múveletekhez, amely mellett ellátásra kerül az érintett tagállamok felügyelete is.

Az Europol foglalkozik továbbá az egyes tagállamok nyomozási technikáinak fejlesztésével, elősegíti a bűnügyi elemzések elvégzését, illetve a tagállamokban folytatott képzések megrendezését is támogatja.

Az Europol feladatai ellátása során felhasználja az Europol Információs Rendszert (EIS), amelyet az Europol bűnügyi adatbázisaként, elsődleges ellenőrző rendszereként is definiálhatunk. A rendszer működtetésének célja, hogy az Európai Unió területén elkövetett súlyos megitélésû (a magyar szabályozás szerint a Btk. szerint legalább 5 év szabadságvesztéssel fenyegetett), és legalább két tagországot érintő és folyamatban levő nyomozásokat összekapcsolja, ezáltal irányt nyújtva és támogatva a nemzeti bűnüldöző hatóságok operatív, műveleti tevékenységét. Így könnyebbé válik az érintett tagállamok közötti kapcsolatfelvétel és a nemzetközi információcsere is.

Fontosnak tartom rögzíteni, hogy magának az Europolnak nincs önálló nyomozati jogköre, azonban központi szerepet játszik az Európa biztonságával foglalkozó uniós és nemzeti szervek között, ennek keretében bűncselekményekkel kapcsolatos információs csatornaként múködik, és egyike a legnagyobb bűnüldözési elemzési kapacitással rendelkező szervezeteknek. A hazai bűnüldöző szervek napi rendszerességgel küldenek és fogadnak bűnügyi információkat az Europol biztonságos információcserét kiszolgáló hálózatán (SIENA-rendszer), így segítve a gyors és hatékony adatcserét a nemzetközi szervezett bűnözés elleni küzdelem terén.

Az Europol szervezetében a saját alkalmazásában lévő szakemberek, szakértők, elemzők mellett megtalálhatók a tagállamok, továbbá az Europollal operatív együttmúködési megállapodást kötő országok összekötő irodái is, amelyek a feladatkörük alapján ellátják a nemzetközi bűnügyi együttmúködésből rájuk delegált tevékenységeket, valamint képviselik hazájukat a különböző országok, szervezetek, intézmények előtt.

A SIENA-rendszerrel kapcsolatos fejlesztéseknek köszönhetően már nem csak a NEBEKen belül múködő Europol Nemzeti Iroda, illetve a hágai Europol Magyar Összekötő Iroda képes részt venni közvetlenül az Europollal történő információcserében, a megkeresések kiküldésében, illetve azok megválaszolásában. Hazánkban SIENA-végpontokat telepítettek

\footnotetext{
${ }^{11}$ Secure Information Exchange Network Application = Biztonságos információcsere-hálózati alkalmazás

${ }^{12}$ Europol Information System = Europol információs rendszer

${ }^{13}$ Europol Analysis System = Europol elemző rendszer

${ }^{14}$ Az Europol négy kulcsfontosságú rendszert használ működése során. Ezek közül a már említett SIENA, EIS és EAS bűnügyi személyes adatok feldolgozására alkalmas, míg a negyedik rendszer, az Europol Platform for Experts (EPE) az Europol munkáját segítő szakértői adatbázis. vö. CSABA Zágon: A bűnelemzés aktuális kihívásai a nemzetközi súlyos és szervezett bűnözés elleni európai fellépés terén. Szakmai Szemle: A Katonai Nemzetbiztonsági Szolgálat Tudományos-Szakmai Folyóirata, 2018/4. szám. pp. 118-132. http://real.mtak.hu/93354/
} 
a szervezett bűnözés és a terrorizmus üldözésében hatáskörrel rendelkező bűnüldöző hatóságokhoz, amelyek már regionális, illetve megyei szinteken közvetlenül is képesek lettek bekapcsolódni a nemzetközi információcserébe. E feladatok ellátására speciálisan felkészített nyomozó kollégák küldenek el, illetve fogadják a megkereséseket, végszik el szükség esetén azok fordítását, továbbítják az Europolnál múködő összekötő irodának az információhoz kapcsolódó adatokat, ahol annak ellenőrzését, illetve esetleges hibajavítását követően a fontos információk eljutnak a címzettekhez. ${ }^{15}$

Ilyen jellegű végponttal és jogosultsággal rendelkeznek a Nemzeti Adó- és Vámhivatal bủnügyi igazgatóságai is.

A nemzetközi bűnügyi együttműködés már igen sok nyomozás sikeréhez járult hozzá. Az egyik közelmúltban történt példa volt, amikor a NAV egy körhintacsalásra szakosodott dunántúli bủnszervezetet számolt fel külföldi bűnüldöző hatóságok és az Europol, illetve az Eurojust támogatásával.

A bűnszervezet táplálék-kiegészítőket és parfümöket „utaztatott” Magyarország és Szlovákia, illetve Magyarország és Csehország között. A számlázási láncolatban egymást váltó bukó cégek mûködtek, amelyek fiktív belföldi értékesítésein keresztül azonosítani tudtuk a haszonhúzó cégeket is, akik európai gazdasági társaságok részére végeztek értékesítést. Az áruk azonban a célországokba történő megérkezésüket követően visszatértek Magyarországra, hogy el lehessen végezni újraértékesítésüket. A számlázási láncok felépítésével és múködtetésével úgy tudtak a társaságok több, mint hárommilliárd forint összegú ÁFÁ-t visszaigényelni, hogy a költségvetésbe egyik cég részéről sem történt befizetés. Az összehangolt eljárási cselekményeknek köszönhetően több, mint egymilliárd forint összegben került sor vagyonbiztosításra, továbbá közel nyolcszáz millió forint összegú ÁFA jogtalan kiutalását is sikerült megelőzni. ${ }^{16}$

\section{Gyakornoki programok az Europolnál}

Az Europol biztosítja a lehetőséget ún. hospitációs programok indítására az ott összekötő irodával rendelkező országok bűnüldöző hatóságai számára annak érdekében, hogy az uniós ügynökség feladatkörébe tartozó szervezett bűnözés és a terrorizmus üldözését a tagállamok szintjén ellátó szervezetek szakértői gyakorlatot szerezhessenek az Europollal történő együttmúködésben. A gyakornoki, vagy más néven hospitációs programokban résztvevő szakértők rutint szereznek a nemzetközi bűnügyi együttmúködés területén, amelynek jelentőségét mind a rendőrség, mind pedig a NAV vezetői felismerték. A programban résztvevők ideiglenesen az Europol központjában, a hollandiai Hágában múködő összekötő irodákhoz kerülnek.

A magyar rendőrség bűnügyi területéről 2006. évben nyílt meg a lehetőség három hónapos idôtartamú, rotációs rendszerủ gyakorlat teljesítésére. A kiküldésre kerülő személyek az Europol Magyar Összekötő Iroda napi munkájába kapcsolódhatnak be, az együttműködés kereteibe pedig az Europolnál megrendezésre kerülő - szakmailag releváns rendezvényeken, például munkacsoportokban történő részvétel keretében nyerhetnek betekintést.

\footnotetext{
15 SZONGOTH - VeTTER i. m. (2018) p. 13.

16 NAV: Nemzetközi akcióban ütött rajta a NAV egy milliárdos bűnszervezeten. 2020. december 03. https://nav.gov.hu/nav/sajtoszoba/hirek/Nemzetkozi akcioban u20201203.html (Letöltve: 2021. március 13.)
} 
A hospitációs program során lehetôség nyililk arra is, hogy a résztvevő kollégák ne csak a magyar összekötő irodán szerezzenek gyakorlatot, hanem a szakmai hátterük szerinti Europol egység munkáját is megismerjék, így ismereteket szereznek a tagállami nyomozásokat támogató feladatokról az Europol munkatársainak szemszögéből is. ${ }^{17}$

A sikeres rendôrségi hospitációs program indulását követôen a NAV is elindította 2011-tôl saját programját, amelyben a mai napig sok pénzügyi nyomozó szerzett értékes és szolgálati helyükre való visszatérésüket követően a napi munkájukat segítő tapasztalatokat.

A hospitációs programokat a Belügyminisztérium a Belső Biztonsági Alapból és a hazai központi költségvetési előirányzatból, vissza nem térítendő támogatásként finanszírozza. E tárgyban a NAV-val kötött támogatási szerződésről NAV honlapján láthatunk a releváns információkat.

2018.04.01. - 2020.09.28. közötti időszakra vonatkozóan a BBA-5.2.1/3-2017-00001 azonosítószámú, „Europol hospitácio” projekt elnevezésű támogatás keretében bruttó 23.150.425 Ft összeg állt rendelkezésre a NAV foglalkoztatottak hospitációjára. Ennek keretében nyolc gyakornok delegálása valósulhatott volna meg, azonban a COVID-19 járvány miatt sajnos csak eggyel kevesebb kiküldésére kerülhetett sor. ${ }^{18}$

Jelenleg az „Europol hospitáció és nemzetközi tanulmányút-sorozat nemzetközi szervezeteknép' elnevezésű projekt fut BBA-5.2.1/10-2019-00001 azonosítószámon, amely 2020.07.01. 2022.12.31. közötti időszakra vonatkozóan biztosítja 10 szakértő Europol hospitációját. E projekt keretében továbbá 5 kéthetes tanulmányút kerül megrendezésre az OLAF, az Eurojust, a Frontex, az Interpol és a SELEC vonatkozásában. Az említett projekt keretében a hatékony nemzetközi információcsere és együttmúködés lehetséges területeinek megismerése a cél a súlyos, szervezett és határon átnyúló bűncselekmények, elsősorban a pénzügyi bűncselekmények megelőzése, felderítése és nyomozása, illetve a SIENA-rendszer hazai alkalmazásával összefüggő feladatok támogatása érdekében. ${ }^{19}$

A hospitánsok tapasztalatcseréje vonatkozásában három, jelenleg is aktív állományú kollégám ismereteit is felhasználom. Az interjúk útján birtokomba jutott ismeretanyagot anonim módon közlöm jelen tanulmányban, mivel az elsődleges célom a gyakorlat bemutatása, nem pedig az egyes hospitáns kollégák részletes úti beszámolóinak publikálása.

Az Europolnál 2016. év IV. negyedévében látogatást tett kollégám (1. számú interjúalany) mind nyílt, mind minősített bűnügyi információkat kezelt gyakornoki feladatai során. Napi munkavégzése mellett lehetősége nyílt az Europol egyes szervezeti egységeihez is eljutni, így bepillantást nyerhetett a különböző, a NAV bűnüldöző tevékenységéhez kapcsolódó munkaterületek mindennapjaiba.

A kiküldetés első két napjában a SIENA-rendszer megismerésére és oktatására tartott képzésen kellett részt vennie. Ezt követően megismerhette az Europol adatbázisában, az EIS-rendszerben ${ }^{20}$ történő keresési, priorálási tevékenységet. Ezek elengedhetetlenek az

\footnotetext{
${ }^{17}$ Kovácsné H. Imola (Szerk.): Europol ismeretbővítés - 2010. p. 2.

18 Belső $\quad$ Biztonsági $\quad$ Alap. 2020.20. https://nav.gov.hu/nav/sajtoszoba/EU finanszirozott projektek/bba folyamatban/folyamatban levo pro jektek/Belso Biztonsagi Alap20190227.html?query=europol (Letöltve: 2021. március 13.)

${ }^{19}$ Belső Biztonsági Alap. i. m. (2020).

${ }^{20}$ Europol Information System
} 
összekötői munka elvégzéséhez, amelyet kollégám az Europol Magyar Összekötői Irodában végzett.

A szervezett bủnözéssel kapcsolatban a SMOKE (jövedéki termékekkel kapcsolatos csalások), az MTIC (határon átnyúló gazdasági kereskedelem során felmerülő ÁFAcsalások), a COPY (termékhamisítások, a hamis áruk kereskedelme, ill. szerzői tulajdonjogok megsértése), a SUSTRANS (pénzmosás, pénzügyi tranzakciók elemzése) és az ASSET RECOVERY (vagyonvisszaszerzés) elemzői projektekkel kapcsolatos munkavégzést ismerhette meg. ${ }^{21}$

Az Europolnál 2018. év IV. negyedévében látogatást tett kollégámnak (2. számú interjúalany) a fentieken túlmenően e-learning tananyagokat (adatvédelmi, biztonsági, az Europol műveleti és stratégiai termékeire vonatkozó modulok) is el kellett sajátítania. Kiküldetését ő is szintén a Magyar Összekötői Irodában teljesítette.

A három hónap során több szakmai programon, megbeszélésen vett részt. Ezek közül az egyik előadás az Europol Mûveleti Központját érintően került megtartásra. Ennek során elhangzott, hogy naponta megközelítőleg háromszáz megkeresés érkezik SIENA-csatornán hozzájuk, amelyeknek nagyjából a kétharmada köthető az Europol mandátumterületéhez. Ezen kérések 80\%-os nagyságrendben a tagországok egyszerű priorálás kérései (személyek, gazdasági társaságok, járművek, telefonszámok lekérdezése) iránti megkeresései. A megkeresések fennmaradó nagyjából 20\%-a pedig kiemelt műveletek támogatása tárgyában érkezik, ezek az Europol elemző projektjeihez (AP) kerülnek továbbításra. ${ }^{22}$

Az Europolnál 2020. év I. negyedévében látogatást tett kollégámnak (3. számú interjúalany) a fentiekkel megegyező feladatai voltak, nála ezek kiegészültek továbbá a más tagországok összekötő tisztjeivel való személyes kapcsolattartással, illetve sajtófigyeléssel is. ${ }^{23}$

A tapasztalatokból látható, hogy a gyakornok kollégák kiküldetésük végére komplexen átlátják az Europol működését, kiterjedt tudást szereznek az Europol által használt rendszerekről, elemzői munkafájlokról és projektekről, és a tagállami bűnüldöző hatóságoknak nyújtott támogató feladatokról. Úgy gondolom, hogy ezt a tudást a bünügyi szolgálatunk tagjai részére olyan módon kell ismertetni, hogy azt a munkavégzésük is hasznosítani tudják.

\section{Pénzügyi nyomozói tapasztalatok és a hospitáció által hasznositható tudás}

Hazánkban a rendészeti feladatokat ellátó szervek személyi állományánál magasfokú fluktuáció tendenciaszerűen tapasztalható, ezzel egyidejűleg pedig az utánpótlást jelentő új generáció a rendészeti munka, mint hivatás gyakorlására csak korlátozott számban toborozhatók. ${ }^{24}$

A fenti megállapítást tényszerűen elfogadva gondolom azt, hogy a fiatal, pályakezdő pénzügyi nyomozók tekintetben a tudatosságnövelés az Europol által biztosított támogató

21 1. számú interjúalany úti beszámolója alapján. Elemzői projekteknek nevezi az Europol azokat a szervezeti egységeit, ahol a projekt hatáskörébe tartozó téma szerinti adatokat feldolgozzák, elemzik, illetve ezekhez kapcsolódóan a korábban már említett támogató feladatokat ellátják. Az elemzői projekteket, mint szervezeti egységeket gyakran AP-nek rövidítik az angol Analysis Project elnevezés alapján.

22 2. számú interjúalany úti beszámolója alapján.

23 3. számú interjúalany úti beszámolója alapján.

${ }^{24}$ CHRISTIÁN László - ERDŐs Ákos: Vészharang és jubileum? A rendészeti felsőoktatás kilátásai, a tisztjelöltek toborzásának és életpályára állításának nehézségei. Belügyi Szuemle, 2020/12. szám pp. 11-42: 13. https://doi.org/10.38146/BSZ.2020.12.1 
szolgáltatások vonatkozásában célszerü, illetve a már néhány év tapasztalatot szerző nyomozók esetében az együttmúködés folyamataira, részleteire is kiterjedő oktatást lenne szükséges tartani. Az Europollal való együttmúködés nyelvi akadályai a Z-generáció esetében nem állnak fenn, hiszen ők szinte kivétel nélkül készségszinten beszélnek angol nyelven, ${ }^{25}$ így a kapcsolattartás lényegesen kisebb kihívás nekik, mint az idôsebb nyomozó korosztály számára. Sőt, ezt a kapcsolattartást pontosan a nyelvtudás használata, annak szinten tartása, és szakirányú fejlesztése miatt nagyon is megkedvelhetik a pályájuk elején tartó nyomozók, és így e területen is sikerélményeket szerezhetnek.

Ugyanakkor lehetséges, hogy több évtizedes tapasztalattal rendelkező pénzügyi nyomozó számára a SIENA-rendszer túl bonyolultnak tűnik, illetve pontosan a nyelvi akadályokból fakadóan idegenkedhetnek tőle. A kérdés kulcsa a bűnügyi tapasztalat és a nyelvi készségek együttes meglétében rejlik, illetőleg abban, hogy ezek a képességek a nemzetközi bűnügyi együttmúködéshez miként használhatók fel?

A nemzetközi bűnügyi együttmúködés nyújtotta lehetőségek lehetőség kihasználatlanul hagyása negatívan befolyásolhatja a nyomozóhatóság eredményességi mutatóit olyan bűnügyi területeken, ahol több ország érintettsége, illetőleg a szervezett bűnözés mutatható ki. A SIENA-rendszer alkalmazásával a birtokunkba jutott információk már a nyomozás elejétől kezdve fontos segítséget nyújthatnak hatóságunknak, előnyökkel járhatnak az elkövetői kör teljesebb feltárásában, és a nyomozás, majd a vádemelés, vagy a bírói szakba kerülő eljárás sikeréhez.

Amennyiben ilyen úton beszerezhető információkról nem értesülünk, az az eljárás sikertelen befejezéséhez vezethet. Természetesen minden ügy más és más, következésképpen nem lehet konzekvensen azt kijelenteni, hogy minden esetben a SIENA-rendszer használatával beszerzett információk vezetnek kizárólag az eljárás sikeréhez. Kétségtelenül előnyös azonban, ha az értesüléseket időben megkapjuk legalább abban, hogy az eljárásunk szempontjából releváns értesülések, illetve bizonyítékok megszerzésére nem a saját hatóságunk szűk erőforrásait kellett igénybe venni, hanem azokat külföldi partnereink a kölcsönösség jegyében rendelkezésünkre bocsájtják. ${ }^{26}$

De nézzük, hogy mi szükséges ahhoz, hogy a SIENA-rendszer, illetve az Europol kínálta egyéb lehetôségek megfelelő módon kamatozzanak eljárásaink során, illetve a pénzügyi nyomozók képzése terén?

Interjúalanyaim arról számoltak be, hogy az Europol gyakornoki program lehetőségéről a nyomozó hatóságnál belső tájékoztatás alapján értesültek, illetve a nemzetközi tapasztalatcsere alternatíváiról már a Rendőrtiszti Főiskolán tudomást szereztek. Ebből fakadóan evidens volt számukra, hogy keressék a hospitációs kiküldetésre jelentkezés lehetőségét. Úgy gondolom, hogy érdemes a lehetőségről széleskörben tájékoztatást adni, hogy minél többen jelentkezzenek a hospitációs programra és annak elvégzését követően a tanultak hozzájárulhassanak az eljárásaink sikeréhez.

Mi motiválta a kollégákat a jelentkezésre? Az 1. számú interjúalanyom szerint mindig találunk olyan személyeket, akik valamely területen tájékozottabbak, tapasztaltabbak, így nagyon is érdemes tanulni tőlük, főként abban az esetben, ha valaki a pályája elején jár. A 2.

25 BERNSCHÜTZ Mária et al.: A Z-generáció jövőjéről - empirikus vizsgálat eredményei. p. 67. http://unipub.lib.uni-corvinus.hu/2514/1/Magyarorszag2025ben p63.pdf (Letöltve: 2021. április 10.)

${ }^{26}$ Vö. az Europol, mint fúziós központtal történő együttműködés előnyei: CSABA i. m. (2018) pp. 118-119. 
és 3. számú interjúalanyom megjelölte továbbá a megszerzett nyelvtudás aktív használatát, annak fejlődését is, mint motiváló tényezőt a program vonatkozásában.

Kollégáim mindannyian több, számukra addig ismeretlen nemzetközi együttmúködési lehetőségrôl tanultak kiküldetésük alkalmával. Ezeket már alkalmazták is konkrét nyomozások során.

Mivel azonban a kiküldetésben részt vevők száma a hely, idő és költségek szempontjából is korlátozott, ésszerű döntés lenne a gyakornoki programban részt vett kollégák tapasztalataira, illetve tudására jobban támaszkodni. Éppen ezért, a hospitált kollégák hazaérkezésüket követően úti jelentést készítenek kiküldetési tevékenységeikről, majd az állomány tájékoztatása céljából prezentációs anyagot állítanak össze az Europol működéséről, az általuk használt rendszerekről, illetve a nemzetközi együttműködés lehetőségeiről, amelyeket ismertetnek szolgálati helyük állományával.

Ezen túl érdemes őket bevonni nemzetközi bűnügyi együttműködést igénylő ügyekbe, de ők lehetnek a jövő a SIENA-rendszer operátorai, vagy azok az összekötők, akik feladata a nemzetközi együttműködés előmozdítása.

\section{A megszerzett tudás átadása a pénzügyi nyomozók részére}

Interjúalanyaim referáltak az Europolnál megszerzett tapasztalataikról, többnyire szolgálati helyük szinte teljes állománya előtt, egy 30-40 perces prezentáció alkalmával.

Véleményem szerint azonban pusztán ez a fajta információközlés nem elegendő a nyomozói állomány részére, amelyben az Europol múködését, illetve a rendelkezésre álló lehetőségeket ismertetik. Egyrészt az előadás időkerete csak áttekintő információk átadására elegendő. Másrészt a beszámolók alkalmával jellemzően nem tud a teljes állomány részt venni, hiszen van, aki az előadás időpontjában például éppen szabadságon van, vagy a nyomozati érdek szól közbe.

Az előadásokra a gyakornok kolléga visszaérkezését követő viszonylag rövid időn belül sor kerül. A bűnügyi szervezet méretéből és tagoltságából fakadóan azonban egy-egy szervnél akár hosszabb idő is eltelik, míg újabb kolléga vehet részt a gyakornoki programban. A két kiküldetés között érkező új kollégák csak legfeljebb közvetett módon szerezhetnek az Europollal való együttmúködés gyakorlati tapasztalatairól tudomást, ráadásul a kiküldések előre nem is láthatók, vagy tervezhetők meg.

Interjúalanyaim példájából kiindulva, jelenleg a NAV Közép-magyarországi Bünügyi Igazgatóságán tendenciaszerűen 5-8 negyedév telik el két hospitáció között. Ez pedig azt jelenti, hogy a gyakorlatban lehet olyan újonnan érkező nyomozó, aki csak azt követő két év múlva hall először az Europolról, illetve a SIENA-rendszerről szóló gyakorlati beszámolót. Úgy gondolom, hogy ez túl nagy idő, ráadásul nem is biztosítja az időközben bekövetkezett változások nyomon követését.

Saját kollégáim mellett interjút készítettem továbbá egy, a Nemzeti Nyomozó Iroda állományába tartozó rendőrtiszttel (4. számú interjúalany) is, hogy összevethessem a két szervezet közötti hospitációs hasonlóságokat, illetve különbségeket. Hasonlóságként könyvelhető el a két szerv között, hogy különös figyelmet fordítanak a nemzetközi bűnügyi együttmúködés csatornáira, az ilyen módon beszerezhető adatokra. 
Különbségként szintén e területen teszek megállapítást. A rendőrség nagyobb számban tud a nemzetközi bűnügyi együttmúködés lehetôségeivel élni, hiszen lényegesen nagyobb létszámú állománnyal és szélesebb nyomozati hatáskörrel rendelkeznek (több bűncselekmény-típus nyomozását végzik), mint a NAV-nál szolgálatot teljesítő nyomozók. Az előzőeken túl sokkal több nemzetközi vonatkozású, illetve bűnszervezetek ellen indított büntetőeljárást folytatnak le, mint a pénzügyi nyomozók. Mivel létszámukat tekintve többen teljesítenek szolgálatot, mint NAV nyomozói, értelemszerűen több nyomozónak nyílik lehetôsége a hospitációra is, amelyet a rendőrségnél megtalálható nagyobb számú SIENAvégpont kezelése is indokolttá tesz.

A rendőrségnél továbbá megvannak azok a speciális területek, ahol napi szinten szükséges a nemzetközi kapcsolattartás, ilyen a kiberbűnözés például, egyúttal pedig több, a nemzetközi bűnügyi együttmúködés szempontjából fontos nemzetközi szervezetben, illetve kétoldalú együttműködés szempontjából frekventált országban rendelkeznek összekötőkkel.

\section{Javaslatok}

Véleményem szerint az Europol hospitáció során a gyakornok kollégák által elsajátított elméleti és gyakorlati tudás hasznosítása a pénzügyi nyomozók képzése terén elengedhetetlenül szükséges, különös tekintettel a fiatal nyomozók oktatására.

A fent említettek szerint a nyomozásokat pozitívan támogathatja meg a SIENA-rendszer használata. Ahhoz viszont, hogy ezt a lehetőséget bátran használjuk, szükséges folyamatosan szinten tartott ismeretekkel rendelkeznünk mind a SIENA-rendszer, mind az Europol által kínált lehetőségekről.

A gyakornoki programot teljesítő kollégák által készített prezentációs anyagot szükséges lenne közzé tenni egy, a nyomozók által is elérhető felületen (BF intranetes oldalán vagy a közös szerver egy, mindenki által hozzáférhetô mappájában).

A megszerzett tudást - a rendőrségi gyakorlathoz hasonlóan - ismertetni lehetne egy-egy, akár a Nemzeti Közszolgálati Egyetemen megtartott szakmai nap alkalmával, ahol bemutatásra kerülhetne a nemzetközi bűnügyi együttmúködés fontossága, illetve annak gyakorlati tapasztalatai, pozitív hozadékai is.

Ugyanakkor akár egy belső, online képzés keretében is indokolttá válhat ezen ismeretanyag elsajátítására való lehetőség kidolgozása. A tananyag elkészítését követôen, autodidakta módon, önképzés keretében sajátíthatnák el az érdeklődő pénzügyi nyomozók a szükséges ismereteket. A képzés - hasonló módon a jelenleg is elérhető kurzusokhoz - egy vizsgával zárulna, amelynek a formája optimálisan egy online tesztsor kitöltése lehetne.

Úgy gondolom másrészt, hogy az ismertetett lehetőségekből fakadó idegennyelv-használat és szakmai fejlődés több fiatal kollégát is hozzásegítene a pénzügyi nyomozói pályán történő hosszabb távon maradáshoz, illetve csökkentené a pályaelhagyást. Figyelemmel a magas fluktuációra, illetve a fiatal pályaelhagyók magas számára, ezt elengedhetetlennek tartom.

Véleményem szerint az Europol hospitációval megszerzett széleskörű tudásanyagot nem szabad veszni hagyni, mert abból sokrétú és pozitív hozadék származik a NAV bűnügyi szolgálata számára. 


\section{Felhasznált irodalom}

[1] A Tanács 2002/465/IB kerethatározata (2002. június 13.) a közös nyomozócsoportokról

[2] Az Európai Parlament és a Tanács (EU) 2016/794 rendelete (2016. május 11.) a Bűnüldözési Együttmúködés Európai Uniós Ügynökségérôl (Europol), valamint a 2009/371/IB, a 2009/934/IB, a 2009/935/IB, a 2009/936/IB és a 2009/968/IB tanácsi határozat felváltásáról és hatályon kívül helyezéséről

[3] Az Európai Rendőrségi Hivatal (Europol) létrehozásáról szóló 2009. április 6.-i, 2009/371/IB számú tanácsi határozat

[4] Belső Biztonsági Alap. 2020. november 20. https://nav.gov.hu/nav/sajtoszoba/EU finanszirozott projektek/bba folyamatba n/folyamatban levo projektek/Belso Biztonsagi Alap20190227.html?query=europ ol (Letöltve: 2021. március 13.)

[5] BERNSCHÜTZ Mária et al.: A Z-generáció jövőjéről - empirikus vizsgálat eredményei. In: Tóth, Attiláné; S., Gubik Andrea (szerk.) Magyarország 2025-ben és kitekintés 2050-re. Tanulmánykötet Nováky Erzsébet 70. születésnapjára. Arisztotelész Kiadó, Bp., $2016 . \quad$ pp. 63-89. corvinus.hu/2514/1/Magyarorszag2025ben p63.pdf

[6] Christián László - ERDŐs Ákos: Vészharang és jubileum? A rendészeti felsőoktatás kilátásai, a tisztjelöltek toborzásának és életpályára állításának nehézségei. Belügyi Szemle, 2020/12. szám. pp. 11-42. https://doi.org/10.38146/BSZ.2020.12.1

[7] CsABA Zágon: A bűnelemzés aktuális kihívásai a nemzetközi súlyos és szervezett bűnözés elleni európai fellépés terén. Szakmai Szemle: A Katonai Nemzetbiztonsági Szolgálat Tudományos-Szakmai Folyóirata, 2018/4. szám. pp. 118-132. http://real.mtak.hu/93354/

[8] Egyezmény az Európai Unióról szóló szerződés K.3. cikke alapján az Európai Rendőrségi Hivatal létrehozásáról

[9] Europol: Az Europolról. 2021. https://www.europol.europa.eu/hu/about-europol (Letöltve: 2021. február 10.)

[10] HoRvÁTH Zoltán: Kézikönyv az Európai Unióról. HVG-Orac Lap- és Könyvkiadó Kft., Bp., 2007.

[11] Kovácsné H. Imola (Szerk.): Europol ismeretbővítés - 2010. (tájékoztató anyag)

[12] NAV: Nemzetközi akcióban ütött rajta a NAV egy milliárdos bűnszervezeten. 2020. december https://nav.gov.hu/nav/sajtoszoba/hirek/Nemzetkozi akcioban u20201203.html (Letöltve: 2021. március 13.)

[13] Nemzeti Adatvédelmi és Információszabadság Hatóság: Tájékoztató EUROPOL rendszerről. https://www.naih.hu/tajekoztato-az-europol-rendszerr-l.html (Letöltve: 2021. március 13.)

[14] pénzügyi nyomozók útibeszámolói

[15] SzOngOTH Richárd - VeTTER Dániel: Nemzetközi bűnügyi együttmúködés a kiberbűnözés területén. Belügyi Szemle 2018/7-8. szám. pp. 7-21. https://doi.org/10.38146/BSZ.2018.7-8.1

\section{Lektor}

Antalóczy Péter, Prof., Dr., intézetvezető egyetemi docens, rendkívüli egyetemi tanár és 
"Tehetség, szorgalom, hivatás"

Csaba Zágon, Dr., PhD., adjunktus pénzügyőr őrnagy

Nemzeti Közszolgálati Egyetem Rendészettudományi Kar Vám- és Pénzügyőri Tanszék

csaba.zagon@uni-nke.hu 